\title{
PHAGE AMPLIFICATION ASSAY AS RAPID METHOD FOR SALMONELLA DETECTION
}

\author{
Regina Silva de Siqueira ${ }^{1 *}$; Christine E.R. Dodd ${ }^{2}$; Catherine E.D. Rees $^{2}$ \\ 'Embrapa Agroindústria de Alimentos, Rio de Janeiro, RJ, Brasil. ²Division of Food Science, University of Nottingham, \\ Sutton Bonington Campus, UK.
}

This paper corresponds to an "extended abstract" selected for oral presentation in the $22^{\text {nd }}$ Brazilian Congress of Microbiology, held in Florianópolis, SC, Brazil, in November 17-20, 2003

\begin{abstract}
The application of rapid methods is crucial for the HACCP program implantation in food industry. In this context, Phage Amplification Assay is a good candidate because is based on the interactions of phage and their host bacteria. This method using phage P22 was applied with to detect Salmonella cells in chicken breast. Samples of $25 \mathrm{~g}$ of chicken breast were diluted and the appropriate dilutions were used in phage amplification assay for Salmonella detection. After 3-4 h of incubation, it was observed a phage titre of approximately $10^{4} \mathrm{pfu} \mathrm{mL}^{-1}$, indicating that there were Salmonella cells which were naturally present in the meat. The presence of Salmonella cells were verified by using direct plating on XLD agar and by conventional enrichment procedure. The colonies suspected to be Salmonella were serologically tested and were identified as belonging to the serogroups B (S. typhimurium group) and D (S. enteritidis group). It can be concluded that this method provides a rapid and alternative application for Salmonella detection in food samples reducing both time and laboratory work to 3-4 hours.
\end{abstract}

Key words: Salmonella, rapid method, bacteriophage, P22.

\section{INTRODUCTION}

Salmonella is an important pathogen for the food industry and it has been a significant bacteriological agent of food-borne outbreaks. However, the whole protocol for their isolation and identification can take 3-6 days or more to yield a conclusive result. Thus, a number of procedures have been described which attempt to simplify the conventional method and reduce the elapsed time involved. The "Phage Amplification Assay" (PAA) was developed by Stewart et al. (4) and is based on the interactions of bacteriophage (phage) and their host bacteria, which can provide rapid and accurate detection of pathogens. This method exploits the lytic cycle of Salmonella-bacteriophage to indicate the presence of low levels of viable Salmonella cells in a sample within few hours. The aim of this study was to evaluate Salmonella phage P22 as an agent for detection of this pathogen by using PAA in chicken breast meat.

\section{MATERIALS AND METHODS}

\section{Bacterial and bacteriophage strains}

The bacteria strain used in this study was Salmonella typhimurium LT-2 (phage propagating strain) and the phage was P22. Phage stock was developed on its appropriate host strain by a plate lysis procedure (3).

\section{Salmonella detection}

$25 \mathrm{~g}$ of chicken breast with skin were aseptically weighed and cut in small pieces, and ten-fold serial dilutions were prepared. The appropriate dilutions were used to detect Salmonella cells applying PAA and to streak out by direct plating on XLD. Additionally, a conventional enrichment procedure (CEP) in Rappaport-Vassiliadis broth, was carried out. Presumptive colonies on XLD were confirmed by serological tests.

*Corresponding author. Mailing address: Embrapa Agroindústria de Alimentos. Av. das Américas, 29.501, Guaratiba. 23.020-470, Rio de Janeiro, RJ, Brasil. Tel.: (+5521) 2410-7454. Fax: (+5521) 2410-1090. E-mail: siqueira@ctaa.embrapa.br 


\section{Phage Amplication Assay (PAA)}

The method was carried out as described by Stewart et al. (4) as $10 \mathrm{~mL}$ of phage P22 carefully mixed with $100 \mathrm{~mL}$ of appropriate sample dilutions. The phage adsorption to bacterial cells was allowed at $37^{\circ} \mathrm{C} / 15$ minutes, followed by the virucidal treatment for 5 minutes at room temperature. The virucidal activity was neutralized and the phage were amplified by adding helper bacteria from undiluted $18 \mathrm{~h}$ culture. Finally, the mixture was transferred to molten top layer agar, poured onto TPA plate, and incubated at $37^{\circ} \mathrm{C} / 3-4 \mathrm{~h}$.

\section{RESULTS}

\section{Salmonella detection by PAA}

The PAA was used to detect Salmonella cells in chicken breast meat. The results of PAA are shown in Table 1. It can be observed that the number of pfu $\mathrm{mL}^{-1}$ recorded was approximately $10^{4}$ pfu $\mathrm{mL}^{-1}$ indicating probably the actual number of bacteria cells since the number of the plaques obtained is correlated to the number of cells in the sample.

\section{Direct plating on XLD and conventional enrichment procedure}

Some small, round and red colonies were observed on XLD by direct plating whilst red colonies without black centers were observed from CEP. These characteristics are typical of Salmonella colonies on this agar as described by Andrews et al. (1) The isolates suspected to be Salmonella were confirmed serologically by Salmonella agglutinating antisera. Most of the isolates were in the $S$. enteritidis group (D). From CEP, the three isolates belonged to $S$. typhimurium group (B) and two isolates belonged to $S$. enteritidis group (D).

Table 1. Detection of Salmonella cells in chicken breast applying PAA.

\begin{tabular}{c|c}
\hline Control Chicken & Number of pfu $\mathrm{ml}^{-1}$ \\
\hline Sample & obtained \\
Sample I & $3.15 \times 10^{4}$ \\
Sample II & $5.10 \times 10^{4}$ \\
Sample III & $1.49 \times 10^{5}$ \\
\hline
\end{tabular}

\section{DISCUSSION}

Detection of Salmonella cells by PAA was investigated. The effectiveness of this method is determined by comparing the number of plaques produced on a lawn of helper bacteria with the number of colonies produced from equivalent sample. From the results of PAA was observed the presence of $10^{4} \mathrm{pfu}$ $\mathrm{mL}^{-1}$ and from counting only (data not shown) indicated approximately $10^{4} \mathrm{cfu} \mathrm{g}^{-1}$ were present in the sample. Thus, it was shown to have a good correlation between the number of plaques observed and the number of cells contained in the sample. From direct plating on XLD, the presence of S. enteritidis serogroup (group D) was found. These findings were supported by Baxa et al. and who reported that phage $\mathrm{P} 22$ is able to infect Salmonella serogroups A, B and D.

\section{CONCLUSION}

Phage P22 was able to infect bacterial cells of S. typhimurium and S. enteritidis. The Phage P22 Amplification Assay can be successful applied and is a good candidate to be used as alternative rapid method.

\section{ACKNOWLEDGEMENT}

Dr. Christine Dodd and Dr. Catherine Rees for their excellent supervision. Also, EMBRAPA (Brazilian Agricultural Research Corporation) for the financial support.

\section{RESUMO}

\section{Amplificação de bacteriófagos como um método rápido de detecção de Salmonella.}

A aplicação de métodos rápidos é crucial para a implantação de programas de HACCP em indústrias de alimentos. Neste contexto, o método de amplificação de bacteriófagos é um instrumento de diagnóstico importante porque está baseado na interação dos bacteriófagos com suas células hospedeiras. Este método, usando o bacteriófago P22, foi aplicado para detectar Salmonella em peito de frango. Amostras de $25 \mathrm{~g}$ de peito de frango foram diluídas e as diluições apropriadas foram usadas no método de amplificação de bacteriófagos na detecção de Salmonella. Após 3-4 horas de incubação, foi observado uma titulação de partículas virais de, aproximadamente, $10^{4}$ ufp $\mathrm{mL}^{-1}$ (unidades formadoras de placas virais), indicando a presença de células de Salmonella na carne de frango. A comprovação da presença de Salmonella neste produto foi verificada usando-se plaqueamento direto em ágar XLD e procedimento de enriquecimento convencional. As colônias suspeitas de Salmonella foram sorologicamente testadas e identificadas como pertencendo aos sorogrupos B (grupo de $S$. typhimurium) e D (grupo de $S$. enteritidis). Portanto, concluiuse que este método pode ser aplicado, na detecção de Salmonella em alimentos, porque fornece rápido e conclusivo resultado, reduzindo o tempo de análise e o trabalho laboratorial para 3-4 horas.

Palavras-chave: Salmonella, método rápido, bacteriófago, P22. 


\section{REFERENCES}

1. Andrews, W.H.; Flowers, R.S.; Sillilker, J.; Bailey, J.S. Salmonella. In: Dowens, F.P.; Ito, K. (eds) Compendium of methods for the microbiological examination of foods. Fourth Edition. American Public Health Association (APHA), Washington, 37:357-380, 2001.

2. Baxa, U.; Steinbacher, S.; Miller, S.; Weintraub, A.; Huber, R.; Seckler, R. Interactions of phage P22 tails with their cellular receptor, Salmonella O-antigen polysaccharide. Bioph. J., 71:20402048, 1996.

3. Sambrook, J.; Fritsch, E.F.; Maniatis, T. Molecular cloning: a laboratory manual. Second Edition. Cold Spring Harbor Laboratory Press, New York, 1989.

4. Stewart, G.S.A.B.; Jassim, S.A.A.; Denyer, S.P.; Newby, P.; Linley, K.; Dhir, V.K. The specific and sensitive detection of bacterial pathogens within 4 h using bacteriophage amplification. J. Appl. Microb., 84:777-783, 1998. 